\title{
The Impact of Paternalistic Leadership Behaviour on Organizational Trust among Healthcare Professionals
}

\author{
Gülfer Bektaş $^{1}$ (D) , Kübra Kanatlı ${ }^{2}$ (iD , Emre İşçi ${ }^{3}$ (iD
}

${ }^{1}$ Acibadem Mehmet Ali Aydinlar University, Faculty of Health Sciences Department of Healthcare Management, Istanbul, Turkey

${ }^{2}$ Acibadem Healthcare Group, Centre of Research and Development Research and Development Associate, Istanbul, Turkey

${ }^{3}$ Marmara University, Faculty of Health Sciences Department of Healthcare Management, Istanbul, Turkey

Gülfer BEKTAŞ

Kübra KANATLI

Emre işçi

Correspondence: Gülfer Bektaş Acibadem Mehmet Ali Aydinlar University, Faculty of Health Sciences

Department of Healthcare Management, Istanbul, Turkey

Phone: +902165004192

E-mail: gulfer.bektas@acibadem.edu.tr

$\begin{array}{ll}\text { Received } & : 24 \text { July } 2021 \\ \text { Accepted } & : 23 \text { September } 2021\end{array}$

\begin{abstract}
Objective: The aim of the current study was to investigate the impact of paternalistic leadership on organizational trust among healthcare professionals. As a starting point, it acknowledges that the impact of paternalistic leadership may vary depending on the cultural values of a given society. The study then offers the regression model between the variables among with implications of this relationship for healthcare management.
\end{abstract}

Methods: A questionnaire-based cross-sectional study and face-to-face interviews were conducted at a private hospital group in Istanbul. The study sample encompassed 329 employees. In data analysis and evaluations, frequency tables, central and prevalence criteria, Pearson's correlation test and simple linear regression analysis were employed and analysed with the SPSS 20 statistical package program.

Results: A statistically significant and positive correlation was found between paternalistic leadership behaviour and organizational trust $\left(r=0.669, p=0.000 ; R^{2}=0.448\right)$. The analysis indicated that paternalistic leadership behaviour explained about $45 \%$ of the variance in organizational trust.

Conclusion: In study, it was found that paternalistic leadership behaviours are strongly related to organizational trust among healthcare professionals. Paternalistic leadership, particularly in collectivist cultures with high power-distance structures, may yield to positive organizational outcomes.

Keywords: Paternal leadership, leadership, organizational trust

\section{Sağlık Çalışanlarında Paternalist Liderlik Yaklaşımının Örgütsel Güven Üzerindeki Etkisi}

ÖZET

Amaç: Sağlık çalışanlarında paternalist liderliğin örgütsel güven üzerindeki etkisini araştırmaktır. Başlangıç noktası olarak, paternalist liderliğin etkisinin toplumun kültürel değerlerine bağlı olarak değişebileceği kabul edilmiş ve bu ilişkinin sağlık yönetimi üzerindeki etkileri ile birlikte değişkenler arasındaki regresyon modelini sunmak amaçlanmıştır.

Yöntem: Araştırma, İstanbul ilinde faaliyet gösteren ve kolayda örnekleme yoluyla belirlenen bir özel grup hastanesinde gerçekleştirilmiştir. Veri toplama aracı olarak anket kullanılmış ve katılımcılara yüz yüze görüşme yoluyla uygulanmıştır. Araştırmanın örnekleminde, araştırmaya katılmayı kabul eden 329 çalışan yer almaktadır. Veriler elektronik ortama aktarılarak, SPSS 20 istatistik paket programında analiz edilmiştir. Analiz ve değerlendirmelerde sıkık tabloları, merkezi ve yaygınlık ölçütleri, Pearson korelasyon testi ve basit doğrusal regresyon analizleri kullanılmıştır.

Bulgular: Elde edilen bulgulara göre, paternalist liderlik davranışı örgütsel güvenin \%45'ini açıklamakta ve paternalist liderlik davranışı ile örgütsel güven arasında istatistiksel olarak anlamlı, pozitif yönde, kuvvetli ilişki bulunmaktadır $\left(r=0.669, p=0.000 ; R^{2}=0.448\right)$.

Sonuç: Çalışmada, sağlık çalışanlarında paternalist liderlik davranışları ile örgütsel güven arasında güçlü bir ilişki olduğu bulunmuştur. Paternalist liderlik, özellikle yüksek güç mesafesi yapılarına sahip kolektivist kültürlerde, olumlu örgütsel sonuçlara yol açabilir.

Anahtar Kelimeler: Babacan Liderlik, liderlik, örgütsel güven 
0 ne of the leadership concepts that has recently come into focus in the past decades is paternalistic leadership. Silin (1976) proposed the concept of paternalistic leadership and the term 'paternalistic' indicates an idea where the leaders perceive their followers as children needing the protection, guidance and guidance of a father in professional and personal development $(1,2,3)$. The employees are expected to trust and commit to their leaders and voluntarily follow their directions (3). Chen and others list three dimensions of paternalistic leadership as authority, benevolence and morality (4). Paternalistic leadership thus appears as an approach encapsulating discipline and authority as well as care and concern for employees.

Paternalistic leadership seems to be a valued approach in collectivistic cultures, compared to individualistic ones, where organizations are often formed in hierarchical structure with high power distance between the leader and employees $(3,5,6)$. Aycan $(2000,2001)$ in her comparative studies on paternalistic leadership, ranked Turkey, China, India, Pakistan and Taiwan among countries with high collectivist cultures $(7,8)$. In recent years, there has been an increasing amount of literature focusing on the impact of paternalistic leadership on organizational dynamics in a workplace. For example, a positive impact of paternalistic leadership on employee performance and productivity $(4,9)$, job satisfaction $(10,11,12,13)$, organizational citizenship (14), working morale (15), organizational justice (16), and positive work engagement behaviour are among many others (17). To the contrary, paternalistic leadership is not widely discussed in Western literature and the existing work tends to underscore negative aspects of this model with individualistic and low power distance observed in the Western societies $(2,18)$.

A concept strongly related to leadership is organizational commitment. Under the model put forth by ShockleyZalabak and others (2000), organizational trust is the overarching belief that an organization in its behaviours and communication is competent, open and honest, concerned, reliable, and worthy of identification with its goals, norms, and values $(19,20)$. In the model developed by Bromiley and Commings (1996), organizational trust is referred to as the beliefs and expectations of employees from organizational relationships and behaviours, encompassing emotional, cognitive and behavioural dimensions $(20,21,22)$. Anderson and others (2012) analysed organizational trust in five dimensions: organizational trust relates to the psychological state of the person, is linked to perceived experiences, refers to positive expectations about the organization and its members, involves actively taking risks, and is subject to change in any situation (23, 24).

As a concept, organizational trust is an essential component of organizational excellence in today's world (25). Recent studies analysing the relationship and impact of organizational trust have linked organizational trust to improved economic performance and the achievement of organizational goals (26), successful cooperation and effectiveness in organizations (27) as well as enhanced organizational learning (24). Thus, previous research emphasises the importance of organizational trust in the effective, equitable and efficient delivery of services, including in healthcare institutions.

The aim of the current study was to investigate the impact of paternalistic leadership approaches on organizational trust among healthcare workers. Since paternalistic leaders closely focus on the well-being and performance of employees in both their professional and personal life, it is plausible to expect the development of trust in leader-member interactions as well as the increase in organizational commitment. Previous studies support the conclusion that paternalistic leadership exerts a positive impact on a variety of dimensions related to organizations, ranging from work engagement to job satisfaction. Therefore, it may be argued that paternalistic leadership is also associated with organizational trust, particularly in collectivist cultures.

\section{Materials and method}

A questionnaire-based cross-sectional study was undertaken in a private hospital in the city of Istanbul operated by the largest private healthcare group in Turkey. The selection of the hospital was determined by a convenience sampling. The study sample included 329 employees. The participation was voluntary, and participants' answers were recorded anonymously. The questionnaire was administered to the employees through face-to-face interviews between 10 December 2019 and 10 January 2020. The study was approved by Acıbadem University and Acıbadem Healthcare Institutions Medical Research Ethics Committee (ATADEK) on 5 December 2019 with the decision of 2019-19/35.

The questionnaire consisted of three parts. The first part collected information on demographics and employeerelated variables. This part included items concerning sex, age (6-point response scale; younger than 25 years, 26-35 years, 36-50 years, 40-49 years, 51-65 years, 66 years or 
older), years of employment at the hospital (4-point response scale; less than a year, 2-4 years, 5-10 years, more than 11 years), years of employment in total (4-point response scale; less than a year, 2-4 years, 5-10 years, more than 11 years), job title/profession (9-point response scale; nurse, physician, healthcare officer, midwife, emergency medical technician, medical secretary and patient services professionals, laborant, $x$-ray technician and another position) and job rotation/shift (3-point response scale; day, night, day and night).

The paternalistic leadership perceptions of the participants were measured by the Paternalistic Leadership Scale developed by Aycan (2006) (5). The responses in this Scale were rated using a five-point Likert-type scale where high scores represent employees who perceived high paternalistic leadership behaviours in their leaders ( $1=$ strongly disagree to $5=$ strongly agree). The Cronbach's alpha coefficients of both scales were determined as high (Cronbach alpha> 0.70).Organizational trust was measured by the Organizational Trust Scale. This scale was developed by Bromiley and Cummings (1996) and later translated into Turkish by Tüzün (2006) in an unpublished doctoral dissertation (21). Each item was rated using a seven-point Likert-type scale where high scores represent employees who possess higher levels of organizational trust to the institution ( $1=$ strongly disagree to $7=$ strongly agree).

Descriptive data were analysed, and reliabilities were computed for organizational trust and paternalistic leadership perceptions. The data was scrutinised using Pearson correlation and hierarchical linear regression analysis to assess the association between organizational trust and paternalistic leadership perceptions. Furthermore, the study employed frequency tables and the central prevalence criteria. The significance level was set at 5\% and the confidence interval at $95 \%$. Data management and analysis was performed using SPSS 20.0.

\section{Results}

The sample ( $n=328,72.3 \%$ females and $27.7 \%$ males) consisted of $14.7 \%$ nurses, $43.8 \%$ medical secretaries and patient services officers and $11.3 \%$ physicians. Thirty-seven per cent were younger than 25 years, 39\% were between 26 and 35 years and $23.8 \%$ were 36 years or older. Twentyseven per cent had less than 1 year of employment at the hospital, $35.8 \%$ between 2 and 4 years, and $26.9 \%$ between 5 and 10 years, and $10.7 \%$ had more than 11 years of employment. With respect to total years of employment, $13.8 \%$ had less than 1 year of employment in total, $30 \%$ between 2 and 4 years, and $32.7 \%$ between 5 and 10 years, and $23.5 \%$ had more than 11 years of employment. Eighty-three per cent worked on dayshifts, $6.4 \%$ on night shifts and the remaining $10 \%$ worked on both day and night shifts. Fifty-eight per cent worked with female managers as their leader, and $42 \%$ worked with male managers (Table 1).

The median values in Table 2 yielded to the organizational trust score averages of the participants at $\dot{X}=5.23$ and to mean scores of paternalistic leadership behaviour as $\dot{X}=$ 3.60.Results of the Pearson's $r$ analysis yielded that there was a significant, positive correlation between the organizational trust and paternalistic leadership behaviours among healthcare workers $(p<0.01)$. Accordingly, a positive and moderate relationship was observed between paternalistic leadership and organizational trust $(r=0.67)$ (Table 3).

The results of the regression analysis in Table 4 demonstrated that paternalistic leadership behaviour positively affects the organizational trust level $(B=1.061, t=16.594$, $p<0.05)$. Forty-five per cent of the total variance regarding the organizational trust level of the employees was explained by the paternalistic leadership behaviour $\left(R^{2}=\right.$ 0.448).Consequently, the results indicated that paternalistic leadership behaviour is a statistically significant predictor of organizational trust variable. Moreover, the linear regression model was determined as follows:

\section{Organizational Trust $(\mathrm{Y})=1.42+1.06 *$ Paternalistic Leadership (X)}

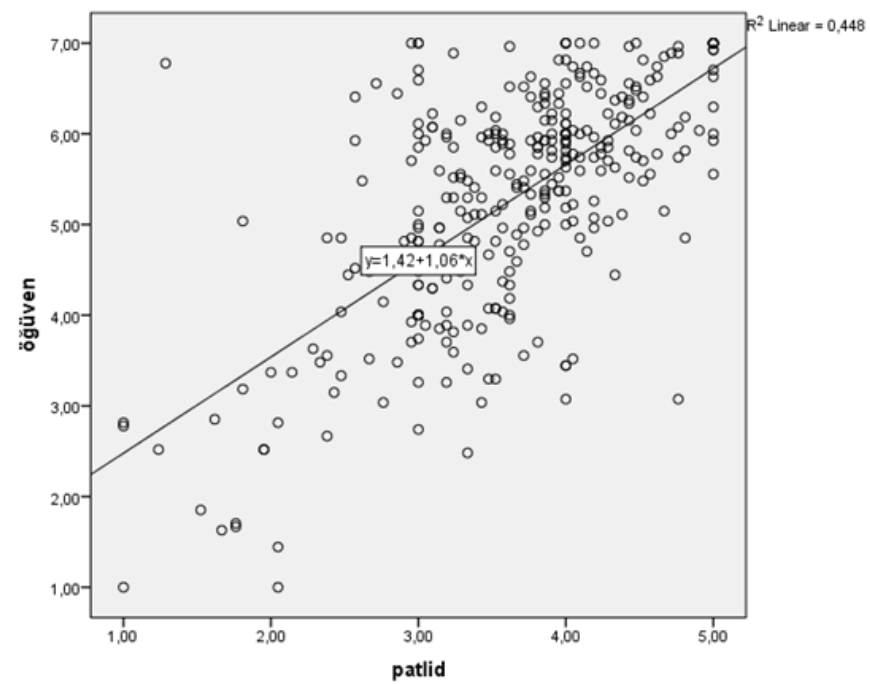

Figure 1. Scatter Plot Relation between Organizational Trust (Y) and Paternalistic Leadership Behaviour (X) 


\section{Table 1. Distribution of the demographic characteristics of participants}

\begin{tabular}{|c|c|c|c|}
\hline & & $f$ & $\%$ \\
\hline \multirow{2}{*}{ Gender } & Female & 237 & 72.3 \\
\hline & Male & 91 & 27.7 \\
\hline Total & & 328 & 100 \\
\hline \multirow{5}{*}{ Age } & $18-25$ & 122 & 37.2 \\
\hline & $26-35$ & 128 & 39.0 \\
\hline & $36-50$ & 59 & 18.0 \\
\hline & $51-65$ & 18 & 5.5 \\
\hline & 66 and over & 1 & 0.3 \\
\hline Total & & 328 & 100 \\
\hline \multirow{5}{*}{ Education } & High school & 70 & 21.5 \\
\hline & Associate degree & 102 & 31.3 \\
\hline & College & 107 & 32.8 \\
\hline & Master's & 27 & 8.3 \\
\hline & $\mathrm{PhD}$ & 20 & 6.1 \\
\hline Total & & 326 & 100 \\
\hline \multirow{4}{*}{ Number of years spent in the profession } & $<1$ year & 45 & 13.8 \\
\hline & $2-4$ years & 98 & 30.0 \\
\hline & $5-10$ years & 107 & 32.7 \\
\hline & $>11$ years & 77 & 23.5 \\
\hline Total & & 327 & 100 \\
\hline \multirow{4}{*}{ Number of years spent in the current workplace } & $<1$ year & 87 & 26.6 \\
\hline & $2-4$ years & 117 & 35.8 \\
\hline & $5-10$ years & 88 & 26.9 \\
\hline & $>11$ years & 35 & 10.7 \\
\hline Total & & 327 & 100 \\
\hline \multirow{3}{*}{ Shift patterns } & Day & 274 & 83.5 \\
\hline & Night & 21 & 6.4 \\
\hline & Day-Night & 33 & 10.1 \\
\hline Total & & 328 & 100 \\
\hline \multirow{9}{*}{ Job title } & Nurse & 47 & 14.7 \\
\hline & Healthcare staff & 3 & 0.9 \\
\hline & Midwife & 3 & 0.9 \\
\hline & Physician & 36 & 11.3 \\
\hline & Medical secretary/ Patient relations officer & 140 & 43.8 \\
\hline & Laborant & 1 & 0.3 \\
\hline & Emergency tecnician & 7 & 2.2 \\
\hline & X-ray technician & 1 & 0.3 \\
\hline & Other & 82 & 25.6 \\
\hline Total & & 320 & 100 \\
\hline \multirow{2}{*}{ Gender of manager } & Female & 183 & 57.9 \\
\hline & Male & 133 & 42.1 \\
\hline Total & & 316 & 100 \\
\hline
\end{tabular}


Table 2. Relationship between Organizational Trust and Paternalistic Leadership Behaviour under the Pearson correlation test

\begin{tabular}{|c|c|c|c|}
\hline & & Organizational Trust & Paternalistic Leadership Behaviour \\
\hline \multirow{4}{*}{ Organizational Trust } & $r$ & 1 & .669 \\
\hline & $\mathrm{p}$ & & .000 \\
\hline & $\mathrm{N}$ & 341 & 341 \\
\hline & $\dot{x}$ & 5.23 & \\
\hline \multirow{4}{*}{ Paternalistic Leadership Behaviour } & $r$ & .669 & 1 \\
\hline & $\mathrm{p}$ & .000 & \\
\hline & $\mathrm{N}$ & 341 & 341 \\
\hline & $\dot{x}$ & & 3.60 \\
\hline
\end{tabular}

Table 3. The amount and total explained variance value of the relationship between variables

\begin{tabular}{|c|c|c|c|c|}
\hline Model & $\mathrm{R}$ & $\mathrm{R}^{2}$ & Adjusted $\mathrm{R}^{2}$ & Standard Error of the Estimate \\
\hline 1 & $.669^{\mathrm{a}}$ & .448 & .447 & .93331 \\
\hline${ }^{* *} p<0,01$ &
\end{tabular}

Table 4. Simple linear regression analysis results of organizational trust and paternalistic leadership behaviour

\begin{tabular}{|l|c|c|c|c|c|}
\hline & \multicolumn{2}{|c|}{ Non-standardized coefficients } & Standardized coefficients & \multirow{2}{*}{$\mathrm{t}$} \\
\hline & $\mathrm{B}$ & Standart error & Beta & 6.024 & .000 \\
\hline Constant & 1.418 & .235 & .669 & 16.594 & .000 \\
\hline Paternalistic leadership behaviour & 1.061 & .064 & & \\
\hline
\end{tabular}

\section{Discussion}

The present study shows that paternalistic leadership behaviour positively influences organizational trust among healthcare workers ( $B=1.061, t=16.594, p<0.05)$. This positive association was moderate $(r=0.669 ; p<0.05)$ (Table 3). The regression model provided as Organizational Trust $(Y)=1.42+1.06 *$ Paternalistic Leadership $(X)$.Significantly, $45 \%$ of the total variance in the level of organizational trust was explained by paternalistic leadership behaviour. This level of effect obtained with a single independent variable was quite high. In other words, it is expected that when healthcare managers display paternalistic leadership behaviour, employee's perceptions of organizational trust increases.

While the association between paternalistic leadership behaviour and organizational trust has not been reported widely in the literature, the studies have reported the associations between paternalistic leadership and employee performance and productivity $(4,9)$, job satisfaction (10, $11,12,13)$, organizational citizenship (14), working morale (15), organizational justice (16), and positive work engagement behaviour (17). For example, in a cross-sectional Turkish study among 683 healthcare workers, Nal and Tarım (2017) found significant and positive correlation between paternalistic leadership behaviours and job satisfaction among healthcare workers $(\beta=530, t=16,322$, $p<0,01)(12)$. In a Turkish study among employees working in banking, insurance, health, education and service sectors, Erben and Güneşer (2008) found a significant and positive relationship between ethics and benevolent paternalistic leadership (28). 
The results of Turkish studies seem to be supported by the results achieved in studies done in other collectivist cultures with high power-distance, such as China, Korea and Taiwan $(7,8)$. A Chinese study by Cheng and others (2004) in the healthcare sector reported that paternalistic leadership behaviouralso guided employees to develop the sense of benevolence in the society (29).Poaching and Chichun (2009) observed that paternalistic leadership behaviour positively impacts organizational citizenship. The present findings seem to be consistent with these studies (14). The present study observed that the increase in organizational trust leads to the increase in work productivity and a trust relationship between employees with their managers, institution and colleagues.In collectivist cultures with high power-distance, membersare perceived toseek protection, support, proximity and attention from their leaders $(3,5,8)$. The paternalistic leadership yields effective results because the paternal leaders with a focus on the emotional and professional needs of their followers, seek to provide solutions to all their problems. Paternal leaders are expected to develop methods to ensure employee loyalty and organizational belonging. Through adopting benevolence in their approach and standing as mentor and a role model, paternalistic leaders display exemplary experience for their employees, and consequently earn organizational trust, as well as achieving greater productivity, work engagement and job satisfaction $(24,26)$.

One practical implication from the present study is that paternalistic leadership approaches in the healthcare sector in Turkey positively impact organizational trust and dynamics, therefore can be an effective management tool in the healthcare industry, particularly in high pressure periods. During the course of the global pandemic on COVID-19, healthcare workers are placed under greater pressure and have been experiencing professional burnout. The paternalistic leadership approaches employed by the management, where leaders consistently show interest in the well-being of their employees (13), may deepen the trust in the organization and, therefore, result in improved economic performance and the achievement of organizational goals, effective cooperation between members as well as enhanced organizational learning.

As for the limitations of the present study, first, although the study was conducted on a large sample, it was limited to a single dependent variable. This implies that organizational dynamics could be further analysed using different variables, models and studies. Secondly, the generability of the current study may be limited. The results may also be culture specific, depending on the collectivist-individualist cultures and power-distance in different societies. Thus, it is suggested that future studies should examine the importance of paternalistic leadership behaviour on organizational commitment across a broad range of health-care organizations in other cultures andcountries and among a broad range of employee groups.

\section{Conclusion}

The current study concluded that paternalistic leadership behaviour positively influences organizational trust among healthcare workers, and this relationship was moderate. Paternalistic leaders closely focus on the wellbeing and performance of employees at work and in their personal lives. It is argued that, in countries with collectivist cultures and high power-distinctions, the interactions between leaders and members under the paternalistic leadership model leads members to develop positive beliefs with respect to organizational relationships and behaviours.

\section{REFERENCES}

1. Silin RH. Leadership and values: The organization of large-scale Taiwanese enterprise. Boston: Harvard University Asia Center; 1976.

2. Anderson J. Servant Leadership and the True Parental Model. School of Leadership Studies Regent University; 2005.

3. Keklik B. Determination of Leadership Style Preferred in Health Institutions: Example of a Private Hospital. Afyon Kocatepe UniversityllBF Journal. 2012; 14(1):73-93.

4. Chen XP, Eberly M, Chiang TJ, Farh JL, Cheng BS. Affective trust in Chinese leaders: Linking paternalistic leadership to employee performance. Journal of management. 2014; 40(3): 796-819. DOI: $10.1177 / 0149206311410604$

5. Aycan, Z. Paternalism: Towards Conceptual Refinement and Operationalization. Scientific Advances in Indigenous Psychologies: Empirical, Philosophical, and Cultural Contributions. London: Cambridge University Press 2006; 445-466.

6. Wren DA. The history of management thought. John Wiley \& Sons; 2005.

7. Aycan Z, Kanungo RN, Mendonca M, Yu K, Deller J, Stahl G, Khurshid A. Impact of Culture on Human Resource Management Practices: A 10-Country Comparison. Applied Psychology: An International Review. 2000; 49(1): 192-221. DOI: 10.1111/1464-0597.00010

8. Aycan Z. Paternalizm: Yönetim ve Liderlik Anlayışına İlişkin Üç Görgül Çalışma. Yönetim Araştırmaları Dergisi. 2001; 1(1):1-31.

9. Uysal ŞA, Keklik B, Erdem R, Çelik R. Examination of the Relationship Between Hospital Managers' Leadership Traits and Levels of the Employees' Work Productivity. Hacettepe Health Administration [Sağlık İdaresi] Journal. 2012; 15(1):25-57.

10. Uçar Z. The Relationship Between Paternalistic Leadership and Job Satisfaction from the Viewpoint of Leading Member Exchange. Bitlis Eren University Journal of Academic Projection. 2019; 4(1):28-49. 
11. Nal M. Sağlık Yöneticilerinin Paternalist Liderlik Davranışlarının Çalışanların İş Doyumu ve Örgütsel Adalet Algısı İlişkilerinin Incelenmesi [Examining the Relationship between Health Managers' Paternalist Leadership Behaviors, Job Satisfaction and Organizational Justice Perceptions among heathcare workers]. Istanbul: Marmara University, 2018.

12. Nal M, Tarım M. The Effect of Paternalist Leadership Behavior by Health Managers on Workers' Job Satisfaction. ACU International Journal of Social Sciences. 2017; 3(2):117-141.

13. Cerit Y. The Relationship Between Paternalistic Leadership and Satisfaction from Administrator and Work. Ondokuz Mayıs Üniversitesi Eğitim Fakültesi Dergisi. 2012; 31(2):35-56.

14. Paoching $\mathrm{C}$, Chichun $\mathrm{H}$. The Relationship of Paternalistic Leadership and Organizational Citizenship Behavior:The Mediating Effect of Upward Communication. Journal of Human Resource and Adult Learning. 2009; 5(2).

15. Chu P, Yang CC. A Study of the Relationships among Paternalistic Leadership and Working Morale: The Mediating Effect of Subordinate-Supervisor Relationship. Journal of Human Resource and Adult Learning. 2009; 5(2):1-14.

16. Nal M. Sağlık Yöneticilerinin Paternalist Liderlik Davranışlarının Çalışanların İş Doyumu ve Örgütsel Adalet Algısı Illişkilerinin Incelenmesi [Examining the Relationship between Health Managers' Paternalist Leadership Behaviors, Job Satisfaction and Organizational Justice Perceptions among heathcare workers]. Istanbul: Marmara University, 2018.

17. Nal M, Sevim E. The Effect of Paternalist Leadership on Work Engagement: A Research on Health Workers. Journal of International Health Sciences and Management. 2020; 6(10): 90-107.

18. Laub, J. From Paternalism to the Servant Organization: Expanding the Organizational Leadership Assessment (AOL) Model. Paper presented at the 2003 Servant Leadership Research Roundtable, Regent University, Virginia Beach, VA.

19. Shockley-Zalabak P, Ellis K, Cesaria R. Measuring organizational trust. San Francisco, CA: IABC Research Foundation; 2000.

20. Bal Taştan S, Isci E. Algılanan Sosyal Adalet, Benlik Kurguları Ve Adil Dünya İnancının Örgütsel Güven IIle Illişkilerinin İncelenmesi: Kültürel Psikoloji Ve Sosyal Biliş Kuramı Açısından Bir Değerlendirme. "Işs, Güç" Industrial Relations and Human Resources Journal. 2016; 18(3):133-158.

21. Bromiley $\mathrm{P}$, Cummings LL. The Organizational Trust Inventory (OTI). Roderick M Kramer, Tom R Tyler (eds), Trust in Organizations, Thousand Oaks, Sage;1996.

22. Kalemci Tüzün İ. Güven, Örgütsel Güven ve Örgütsel Güven Modelleri [Organizational Trust and Organizational Trust Models]. Karamanoğlu Mehmetbey Üniversitesi Sosyal ve Ekonomik Araştırmalar Dergisi. 2007; (2): 93-118.

23. Anderson P, Cooper C, Layard R, Litchfield P, Jane-Llopis E. Wellbeing and global success-A report prepared by the World Economic Forum Global Agenda Council on health \& well-being. World Econ Forum 2012: 5-8.

24. Jiang $Y$, Chen W. Effects of Organizational Trust on Organizational Learning and Creativity, EURASIA Journal of Mathematics Science and Technology Education. 2017; 13(6):2057-2068. DOI: 10.12973/ eurasia.2017.01213a

25. Morreale SP, Shockley-Zalabak P. A Qualitative Study of Organizational Trust: Leaders' Perceptions in Organizations in Poland and Russia. Intercultural Communication Studies. 2014; 23(2): 69-89. DOI: 10.1080/17475759.2014.989255

26. Covey MR, Merrill R. The speed of trust: The one thing that changes everything. New York: Free Press; 2008.

27. Paliszkiewicz J. Inter-organizational trust: Conceptualization and measurement. International Journal of Performance Measurement. 2011; 1: 15-28.
28. Erben GS, Güneşer AB. The Relationship Between Paternalistic Leadership and Organizational Commitment: Investigating the Role of Climate Regarding Ethics. Journal of Business Ethics. 2008; 82: 955-968.

29. Cheng BS, Chou LF, WTY, Huang MP, Farh JL. Paternalistic Leadership and Subordinate Responses: Establishing A Leadership Model in Chinese Organizations. Asian Journal of Social Psychology. 2004; 7(1): 89-117. DOI: 10.1111/j.1467-839X.2004.00137.x 